\title{
Traditional uses, phytochemistry, and pharmacological activities of Cochlospermum tinctorium A. Rich (Cochlospermaceae): a review
}

\author{
Mubarak Hussaini Ahmad ${ }^{1,2^{*}}$ (D, Abubakar Ibrahim Jatau ${ }^{3}$, Garba M. Khalid ${ }^{4,5}$ and Omar Yahya Alshargi ${ }^{6}$
}

\begin{abstract}
Background: The plant Cochlospermum tinctorium A. Rich is a sub-shrub that belongs to the family Cochlospermaceae. The plant has been used in traditional medicine for the treatment of malaria, rickets, stomachache, diarrhea, gastric ulcer, parasitic infestations, liver diseases, fever, pain, inflammation, infectious diseases, epilepsy, snake bite, burns, orchitis, labour, menstrual problems, and many other diseases. This review summarizes the traditional uses, phytochemistry, and pharmacological activities of Cochlospermum tinctorium.

Main text: To date, few bioactive molecules have been identified and isolated from the plant such as 7,3dimethyldihydroquercelin, 5,4-dimethylquercelin, cochloxanthine, dihydrocochloxanthine, arjunolic acid, 3-O-E-pcoumaroylalphitolic acid, alphitolic acid, 1-hydroxytetradecan-3-one, 3-bisabolen, 2-tridecanone, 3-hexadecanone, 1dodecanol, I-tetradecanol, 2-pentdecanone, 3-octadecanone, 1-hydroxy-3-hexadecanone, 1-nonadecanol, I-O-acetyl3-hexadecanone, and I-hydroxy-3-oetadecanone. The literature related some of the reported ethnomedicinal uses of the plant to these compounds found in the different parts of the plant.

Conclusion: The comprehensive information documented in this review about the importance of the C. tinctorium may provide an opportunity for research advancement in drug discovery and a better understanding of the medicinal benefits of the plant.
\end{abstract}

Keywords: Active compounds, Cochlospermum tinctorium, Medicinal plant, Novel compounds, Pharmacological activity, Phytochemistry, Traditional uses

\section{Background}

For decades, humans majorly rely on plants for food and management of diseases [1]. It is estimated that approximately $75 \%$ of the global population relies on herbal medicines for their basic health care needs. Indeed, many drugs that are currently in use in modern medicine are obtained from plants [2]. Given the

\footnotetext{
* Correspondence: mubarakhussainiahmad@gmail.com

'Department of Pharmacology and Therapeutics, Ahmadu Bello University, Zaria, Nigeria

${ }^{2}$ School of Pharmacy Technician, Aminu Dabo College of Health Sciences and Technology, Kano, Nigeria

Full list of author information is available at the end of the article
}

predominant uses of medicinal plants in traditional medicine, there is an upsurge in research to investigate the active medicinal compounds, efficacy, and safety of such plants [3]. The literature suggests that the search for novel therapeutic compounds based on traditional uses and folkloric information about medicinal plants obtained from the community could guide and serve as a potential strategy for the development of new therapeutic compounds. Therefore, there is need for data and high quality-research on medicinal plants to provide stronger scientific evidence and confirm their medicinal uses and safety in traditional medicines.

\section{Springer Open}

(c) The Author(s). 2021 Open Access This article is licensed under a Creative Commons Attribution 4.0 International License, which permits use, sharing, adaptation, distribution and reproduction in any medium or format, as long as you give appropriate credit to the original author(s) and the source, provide a link to the Creative Commons licence, and indicate if changes were made. The images or other third party material in this article are included in the article's Creative Commons licence, unless indicated otherwise in a credit line to the material. If material is not included in the article's Creative Commons licence and your intended use is not permitted by statutory regulation or exceeds the permitted use, you will need to obtain permission directly from the copyright holder. To view a copy of this licence, visit http://creativecommons.org/licenses/by/4.0/. 
The plant Cochlospermum tinctorium A. Rich (Cochlospermaceae) has been used for years in traditional medicine for the treatment of various ailments in many African countries such as Ivory Coast, Ghana, Cameroon, Nigeria, Gambia, Guinea, Senegal, Burkina Faso, and many others [4]. The plant is predominantly available in the savannah and throughout the dried parts of West Africa. It is locally called Oja Ikoko or Sewutu (Yoruba), Obazi or Abanzi (Igbo), and Rawaya or Kyamba (Hausa) languages of Nigeria [5]. Recently, C. tinctorium has gained attention from scientific community as a result of its traditional and wide range of medicinal uses. A review by Haidara et al. focused on the antimalarial and hepatoprotective activities of $C$. tinctorium and other medicinal plants used in Malian traditional medicine for the management of malaria and liver diseases [6]. However, studies reporting the traditional uses, phytochemical profile, and pharmacological activities of the plant are limited. Therefore, we conducted a review of the literature to provide comprehensive information related to the traditional uses, phytochemical contents, and pharmacological activities of the plant with a mission to stimulate further research on its potentials for the development of novel therapeutic compounds.

\section{Botanical description of Coclospermum tinctorium}

The plant $C$. tinctorium belongs to the family Cochlospermaceae. The family consists of seven genera which include Amoreuxia, Azeredia, Cochlospermum, Euryanathe, Lachnocistus, Maximilianea, and Wittelsbachia [7]. The genus Cochlospermum Kunth (syn. Maximilianea Marth., Bixaceae) consists of some tropical species such as C. tinctorium, C. planchonii, C. angolense, C. vitifolium, C. regium, C. orinocense, C. religiosum, C. gillivraei, C. wittei, $C$. tetraporum, C. intermedium, and C. fraseri [8]. The two species $C$. planchonii and $C$. tinctorium are widely available in West Africa [9]. The plant $C$. tinctorium is a sub-shrub which is about $80 \mathrm{~cm}$ in length with a woody subterranean root stock that produces its shoots annually [10]. The leaves of the plant are alternate with lobes lanceolate to oblong, basally connate for up to $25 \%$ of their length [10]. The plant possesses few inflorescences and flowered panicle or raceme, usually produced at ground level from the rootstock, sometimes appearing on top of leafy shoots [10] (Fig. 1). The fruits of C. tinctorium are elongated about $3-5$ valve and its capsules containing seeds are embedded in the cotton foam. The seeds are colored ranging from brown to black with a bean-shape. The endosperm of the plant is oily with broad cotyledon [12].

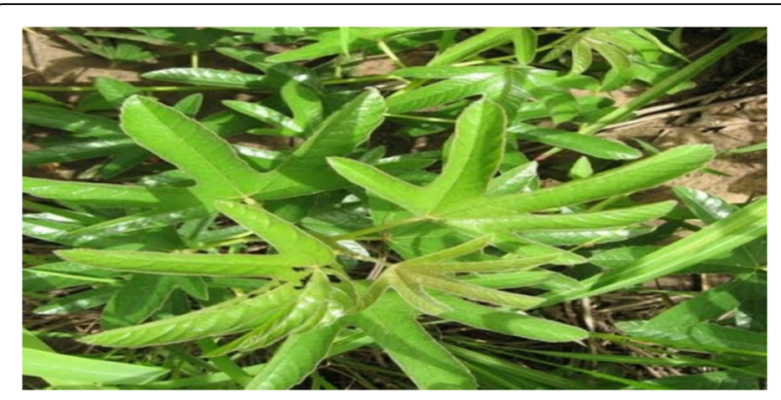

Fig. 1 The plant Cochlospermum tinctorium in its natural habitat adopted from [11]

\section{Main text}

Traditional uses of Cochlospermum tinctorium

The plant $C$. tinctorium is the most commonly used among all the species of the family Cochlospermaceae [8]. The roots or rhizome are mixed with shea butter oil or other oils and applied for the management of burns [13].

The roots of C. tinctorium are used to treat ulcer [14], liver diseases [15], syphilis, hemorrhoids, intestinal worms, measles, rheumatism, yellow fever [8], gonorrhea [16], jaundice, snake bites, indigestion, convulsion, pneumonia, and bronchial infections [13]. The roots of the plant have also been used for women in labour and to alleviate menstrual pain [13]. The roots decoction or infusion are taken with other herbs for the treatment of malaria [5], urethral discharges, orchitis, and fever [13]. In addition, the roots of $C$. tinctorium are used in traditional medicine for the treatment of infectious diseases [17], diabetes mellitus [18], epilepsy [19], pain and inflammation [20], conjunctivitis, leprosy, and testicular inflammation [8].

The rhizomes of $C$. tinctorium are used as a decoction for the treatment of rickets, stomach pain, helminthiasis, beriberi [21], fever, hepatitis, abdominal pain, and bilharzia [18]. The leaves of C. tinctorium are used for the management of diarrhea [22], abscess, and boils [8], while the flowers are used against constipation [8]. The summary of the documented traditional uses of different parts of C. tinctorium and scientific confirmation of their pharmacological activity is presented in Table 1 .

\section{Phytochemistry of Cochlospermum tinctorium}

The biological activities of medicinal plants mainly depend on the presence of phytochemical contents and other bioactive compounds that contribute to the discovery and development of novel therapeutic agents. These secondary metabolites include alkaloids, glycosides, flavonoids, proanthocyanidins, tannins, terpenoids, phenylpropanoids, resins, lignans, furocoumarins, naphthodianthrones, proteins, and peptides [35]. Essential oils sourced from medicinal and other aromatic 
Table 1 Traditional uses of different parts of Cochlospermum tinctorium and scientific confirmation of their pharmacological activity

\begin{tabular}{|c|c|c|c|}
\hline Traditional uses & Plant part & References & Confirmation of pharmacological activity \\
\hline Abscesses and boils & Leaves & [8] & Not confirmed \\
\hline Beriberi and burns & Rhizomes & {$[13,21]$} & Not confirmed \\
\hline Bilharzia & Rhizomes & [18] & Not confirmed \\
\hline Bronchial infections & Roots & [13] & Not confirmed \\
\hline Constipation & Flowers & [8] & Not confirmed \\
\hline Convulsion & Roots & {$[13,19]$} & Not confirmed \\
\hline Diabetes mellitus & Roots & {$[16,18]$} & Not confirmed \\
\hline Diarrhoea & Leaves & [22] & Confirmed [22] \\
\hline Pain and inflammation & Roots & [20] & Confirmed [20] \\
\hline Fever and rheumatism & Roots & {$[8,13]$} & Not confirmed \\
\hline Helminthiasis, worms & Rhizomes & {$[8,21]$} & Confirmed [23] \\
\hline Infectious diseases & Roots & {$[17]$} & Confirmed $[22,24-26]$ \\
\hline Gonorrhea and measles & Roots & {$[8,16]$} & Not confirmed \\
\hline Hepatitis and hemorrhoids & Roots and rhizomes & {$[8,18]$} & Not confirmed \\
\hline Indigestion, jaundice, labour & Roots & [13] & Not confirmed \\
\hline Syphilis & Roots & [8] & Not confirmed \\
\hline Leprosy, testicular inflammation & Not specified & [8] & Not confirmed \\
\hline conjunctivitis, yellow fever & Not specified & [8] & Not confirmed \\
\hline Liver diseases & Roots & [15] & Confirmed $[6,21,27-31]$ \\
\hline Malaria & Roots & [5] & Confirmed $[5,32-34]$ \\
\hline Menstruation problem, orchitis and pneumonia & Roots & [13] & Not confirmed \\
\hline Rickets and stomach pain & Rhizomes & {$[13,21]$} & Not confirmed \\
\hline Snake bite, urethral discharge & Roots & {$[13,14]$} & Not confirmed \\
\hline Ulcer & Roots & [14] & Confirmed [15] \\
\hline
\end{tabular}

plants have also been described as a potential source of compounds for pharmaceutical and industrial use because of their efficacy and safety [35].

\section{Volatile oil composition of Cochlospermum tinctorium}

The essential oil obtained from the leaves of $C$. tinctorium was reported to contain aliphatic ketones including 1-hydroxytetradecan-3-one, 1-hydroxyundecan-3-one, 1hydroxytridecan-3-one, and 1-hydroxyheptadecan-3-one; aldehydes, esters, and terpenoids [32]. The major components of the oil are linalool $(0.3 \%), \alpha$-terpineol $(0.3 \%)$, $\alpha$-copaene $(0.4 \%), \quad \beta$-bourbonene $(0.4 \%), \quad \beta$-elemene (0.4\%), $\beta$-caryophyllene (3.1\%), $\beta$-cubebene $(0.1 \%)$, (trans)- $\alpha$-bergamotene $(0.3 \%),(\mathrm{Z})-\beta$-farnesene $(1.2 \%), \alpha$ humulene $(0.8 \%)$, dodecanol $(0.8 \%)$, y-muurolene $(0.6)$, germacrene-D (2.4\%), bicyclogermacrene (0.9\%), tridecan-2-one $(1.2 \%)$, widdrene $(0.3 \%)$, dihydroactinidiolide $(0.3 \%), \alpha$-selinene $(1.0 \%), \alpha$-muurolene $(0.7 \%),(\mathrm{E}$, E)- $\alpha$-farnesene (1.6\%), $\beta$-bisabolene $(0.2 \%), y$-cadinene $(0.3 \%)$, calamenene $(0.1 \%), 7$-epi- $\alpha$-selinene $(0.4 \%), \delta$ cadinene $(2.8 \%)$, calacorene $(0.1 \%), \alpha$-cadinene $(0.2 \%)$, germacrene-B (1.8\%), 1-hydroxyundecan-3-one (1.8\%), spathulenol (0.2\%), caryophyllene oxide (0.7\%), tetradecan-3-one (9.2\%), globulol (0.3\%), y-endesmol (0.4\%), tetradecanal (3.3\%), epi-y-endesmol (0.6\%), $\alpha-$ copaen-8-ol $(0.6 \%)$, caryophylladienol I $(0.2 \%)$, caryophylladienol II (0.4\%), cadinoI (5.1\%), muurolol (0.4\%), $\alpha$-cadinol (5.8\%), 1-tetradecanol (7.3\%), pentadecan-2-one (1.0), 1hydroxytridecan-3-one (0.2\%), hexadecan-3-one (7.8\%), tetradecyl acetate (5.2\%), hexadecanal (0.5\%), isopropyl myristate (1.2\%), 6,10,14-trimethyl pentadecan-2-one (1.2\%), neophytadiene I (3.1\%), 1-hexadecanol (1.0\%), 1hydroxypentadecan-3-one (1.7\%), isophytol (0.3\%), octadecanal $(0.3 \%)$, octadecan-3-one $(0.3 \%)$, hexadecyl acetate (1.1\%), 1-heptadecanol (0.1\%), phytol (9.4\%), 1-hydroxyheptadecan-3-one (1.1\%), $\mathrm{C}_{15} \mathrm{H}_{24} \mathrm{O}$ (2.5\%), and $\mathrm{C}_{15} \mathrm{H}_{26} \mathrm{O}(0.7 \%)$ [32]. Other compounds obtained from the essential oils of $C$. tinctorium are 3tetradecanone, 3-hexadecanone, 2-tridecanone, cyclododecanone, dodecyl acetate, methyl tetradecanoate, and 1-tetradecanol acetate [36].

\section{Identified and isolated bioactive compounds from Cochlospermum tinctorium}

Previous research conducted by Diallo and colleagues has shown that the rhizome of $C$. tinctorium contains 
7,3-dimethyldihydroquercelin, 5,4-dimethylquercelin, cochloxanthine, dihydrocochloxanthine, and arjunolic acid [27]. Another study by Ballin et al. reported the presence of 3-O-E-p-coumaroylalphitolic acid, cochloxanthine, dihydrocochloxanthine, alphitolic acid, and 1-hydroxytetradecan-3-one in the dichloromethane fraction of ethanol root extract of the plant [5]. Furthermore, Diallo et al. isolated 3-bisabolen, 2tridecanone, 3-hexadecanone, 1-dodecanol, l-tetradecanol, 2-pentdecanone, 3-octadecanone, 1-hydroxy-3-hexadecanone, 1-nonadecanol, 1-O-acetyl-3-hexadecanone, 1hydroxy-3-oetadecanone from the rhizome extract of the plant [37]. The main compounds cochloxanthine and dihydrocochloxanthine were isolated from the ethanol rhizome extract of $C$. tinctorium using high-performance liquid chromatography-ultraviolet (HPLC-UV) $[9,38]$. The rhizome of the plant was reported to contains carotenoids, phenolic compounds (gallic and ellagic acid) and triacylbenzenes (cochlospermines $\mathrm{A}, \mathrm{B}, \mathrm{C}, \mathrm{D}$ ) in the non-polar fractions of the plant extract [21].
A study by Abdulaziz et al. demonstrated that the methanolic root extract of $C$. tinctorium analyzed using column chromatography afforded methanol:ethyl acetate $(80: 20 \% \mathrm{v} / \mathrm{v})$, methanol:ethyl acetate $(60: 40 \% \mathrm{v} / \mathrm{v})$, and $100 \%$ ethyl acetate fractions [12]. The volatile organic compounds identified in the active methanol:ethyl acetate $(80: 20 \% \mathrm{v} / \mathrm{v})$ fraction are tris (trimethylsilyl) amine, undecane, 3-methylene, 3-tetradecanone, undecyl acetate, 1-tridecene, 2-heptanone, 4-methyl-saccharin, heptanoic acid, 2-ethyl-methyl ester tridecane, 3methylene-3-hexadecanone, 1-hexadecanol acetate, butanoic acid, 3-methyl-3,7-dimethyl-6-octenyl ester, 3, 3-dimethyl-4-heptanol, (R)-(-)-(Z)-14-methy-8-hexadecen-1-ol, 5-hexyn-1-ol, lauric acid, isopentyl ester, heptanal, n-heptaldehyde, 1-exadecanol acetate, stearic acid ethyl ester, oleyl alcohol, trifluoroacetate, tridecane, 3-methylene- oleyl alcohol, and trifluoroacetat [12]. Other volatile organic compounds identified in the active ethyl acetate $(100 \%)$ fraction are cyclotrisiloxane hexamethyl, 4-isothiazolecarboxamide, silane, trimethyl

Table 2 Bioactive compounds isolated from Cochlospermum tinctorium and their pharmacological activities

\begin{tabular}{|c|c|c|c|}
\hline Activity & Compound & Mode of assay & References \\
\hline \multirow[t]{5}{*}{ Antiplasmodial } & 3-O-E-p-coumaroylalphitolic acid & In vitro & [5] \\
\hline & Alphitolic acid & In vitro & [5] \\
\hline & Betulinic acid & In vitro & [5] \\
\hline & 3-tetradecanone & In vitro & [39] \\
\hline & 3-hexadecanone & In vitro & [39] \\
\hline \multirow[t]{4}{*}{ Antitumor } & Arjunolic acid & In vitro & [40] \\
\hline & Arjunolic acid methylester & In vitro & [40] \\
\hline & Arjunolic acid triacetate & In vitro and in vivo & [40] \\
\hline & Arjunolic acid triacetate methylester & In vitro and in vivo & {$[40,41]$} \\
\hline Antimicrobial & Carotenoid & In vitro & [42] \\
\hline NP & 7,3-dimethyldihydroquercelin & NP & [27] \\
\hline NP & 5,4-dimethylquercelin & NP & [27] \\
\hline NP & Cochloxanthine & NP & [27] \\
\hline NP & Dihydrocochloxanthine & NP & [27] \\
\hline NP & 3-bisabolen, 2-tridecanone & NP & [37] \\
\hline NP & 3-hexadecanone & NP & [37] \\
\hline NP & 1-dodecanol & NP & [37] \\
\hline NP & I-tetradecanol & NP & [37] \\
\hline NP & 2-pentdecanone & NP & [37] \\
\hline NP & 3-octadecanone & NP & [37] \\
\hline NP & 1-hydroxy-3-hexadecanone & NP & [37] \\
\hline NP & 1-nonadecanol & NP & [37] \\
\hline NP & I-O-acetyl-3-hexadecanone & NP & [37] \\
\hline NP & I-hydroxy-3-oetadecanone & NP & [37] \\
\hline NP & Cochlospermin (A, B, C and D) & NP & [21] \\
\hline
\end{tabular}

NP: no pharmacological screening conducted 
(2-phenylethoxy), omega-phenylacetic acid, benzeneethanol, 4-hydroxy-pyrazolo[5,1-c]-as-triazine, 1,2-butadiene,1,1,4triphenyl-3-trimethylsilyl-4-trimethylsilyloxy, diethyl phthalate 1,1-(+)-ascorbic acid 2,6-dihexadecanoate, heptanoic acid, 2-ethyl-, i-propyl 9,12-octadecenadienoate [12]. The major compounds identified in the methanol root fractions of C. tinctorium using gas chromatography-mass spectrometry (GC-MS) were 1-(+)-ascorbic acid 2,6-dihexadecanoate, diethyl phthalate, undecyl acetate, 3-tetradecanone, and 3hexadecanone [12]. The summary of the isolated compounds from $C$. tinctorium and their documented pharmacological activities is presented in Table 2. Also, the chemical structures of some compounds isolated from $C$. tinctorium are presented in Fig. 2.

\section{Preliminary phytochemical constituents presence in Cochlospermum tinctorium}

Nergard et al. reported the presence of polyphenols, polysaccharides, gallotannins, and ferullic acid in the aqueous root extract of C. tinctorium [15]. Indeed, Tijjani et al. reported the presence of tannins, cardiac glycosides, and flavonoids in the methanol rhizome extract of C. tinctorium [24]. In 2012, Musa reported the presence of anthraquinones, cardiac glycosides, flavonoids, saponins, and carbohydrates in the $80 \%$ acetone fraction of $C$. tinctorium, while its n-butanol fraction showed the presence of cardiac glycosides, saponins, and carbohydrates [13]. The aqueous methanol (leaf, root, and root bark) extracts of the plant revealed the presence of saponins, flavonoids, tannins, steroids, cardiac glycosides, and alkaloids [20]. Etuk et al. also reported the presence of alkaloids, tannins, cardiac glycosides, saponins, flavonoids, triterpenes, cyanogenic glycosides, and volatile oils in the aqueous root extract of $C$. tinctorium [28]. Ndouyang and co-workers reported the presence of secondary metabolites such as tannins (total, hydrolysable, and condensed), phytates, oxalates, carotenoids, cyanides, alkaloids, flavonoids, and phenols in the root of C. tinctorium [18].

\section{Carbohydrate composition of Cochlospermum tinctorium}

The crude water extract of $C$. tinctorium revealed the presence of starch, glucose, arabinose, rhamnose, galactose, xylose, glucoronic acid, galacturonic acid, mannose, and fructose [14]. The isolated pectin polysaccharides from the aqueous extract were reported to be majorly

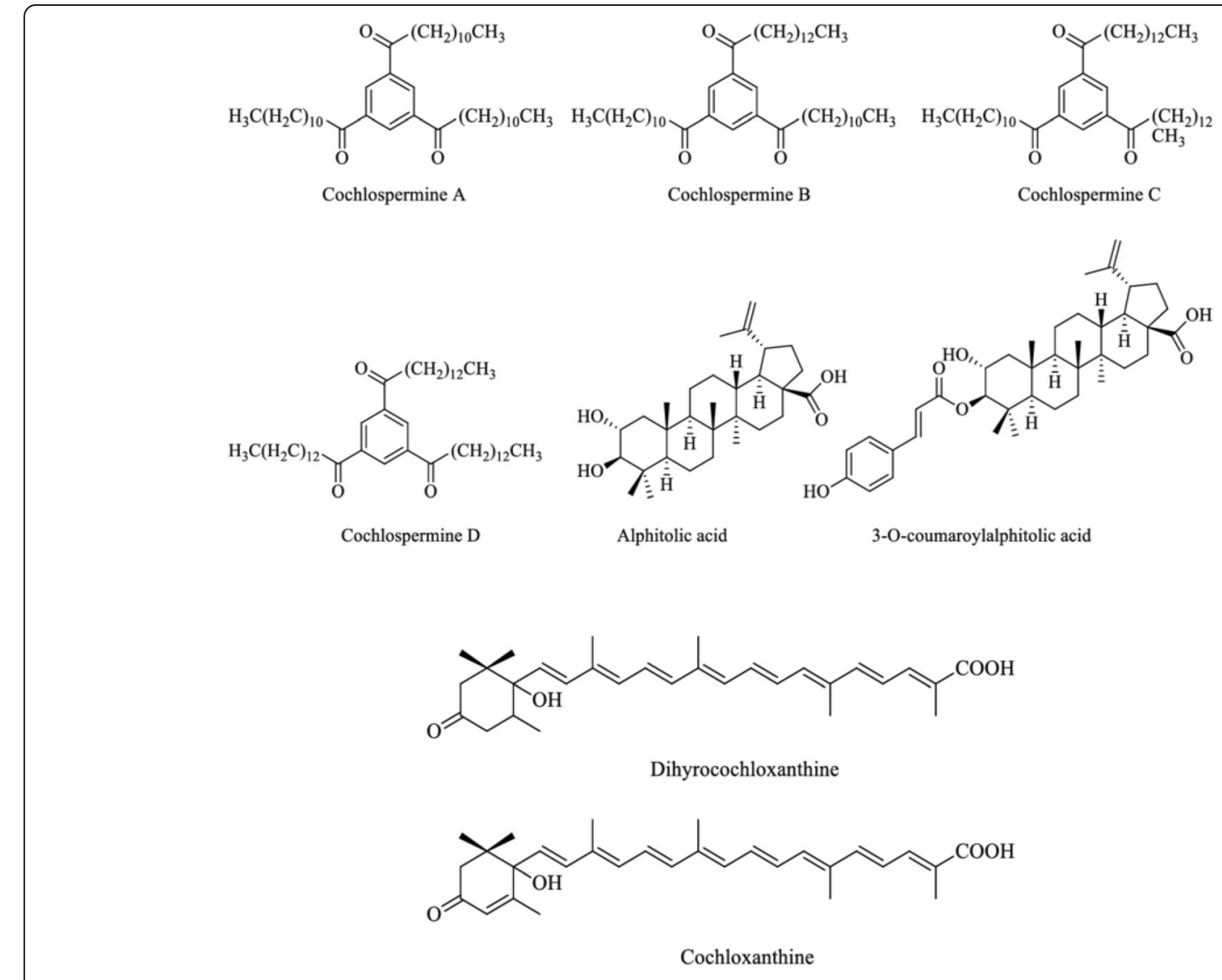

Fig. 2 Chemical structures of some bioactive compounds from Cochlospermum tinctorium [43] 
rich in galactose A, arabinogalactan, homogalacturonan, rhamnogalacturonan I, and substituted galacturonan such as rhamnogalacturonan II [14].

\section{Pharmacological Activities of Cochlospermum tinctorium}

Different extracts obtained from various parts of C. tinctorium have been screened for biological activities including antiplasmodial, anti-ulcer, antioxidant, cytotoxic, antimicrobial, antitumor, antihelmintic, hepatoprotective and hepatocurative, antinociceptive, antidiarrheal, and antiepileptic potentials. The summary of the documented pharmacological activities of different extracts and fractions obtained from different parts of the plant is presented in Table 3.

Antiplasmodial activity A study by Benoit et al. has shown that the aqueous leaf extract of $C$. tinctorium and its essential oil produced effective antiplasmodial activity against Plasmodium falciparum with concentration that produced $50 \%$ inhibition of the in vitro malaria parasite growth $\left(\mathrm{IC}_{50}=3.8-7.5 \mu \mathrm{g} / \mathrm{ml}\right.$ and $\mathrm{IC}_{50}=140-500 \mu \mathrm{g} /$ $\mathrm{ml})$ respectively [32]. The extract elicited antiplasmodial activity in a similar manner to Azadirachta indica $\left(\mathrm{IC}_{50}\right.$ $=4.17-7.29 \mu \mathrm{g} / \mathrm{ml}$ ) [32].

The ethanol root extract of C. tinctorium showed a remarkable antiplasmodial activity [5]. Similarly, the 3$O-E$ - $p$-coumaroylalphitolic acid isolated from the dichloromethane fraction of the ethanol root extract of C. tinctorium demonstrated significant antiplasmodial activity against chloroquine-sensitive $P$. falciparum strain $\left(\mathrm{IC}_{50}=2.3 \mu \mathrm{g} / \mathrm{ml}\right)$, chloroquine-resistant P. falcifarum strain $\left(\mathrm{IC}_{50}=3.8 \mu \mathrm{g} / \mathrm{ml}\right)$, and phytohaemagglutinin A-Activated human lymphocytes $\left(\mathrm{IC}_{50}=43 \mu \mathrm{g} / \mathrm{ml}\right)$ [5]. The antiplasmodial activity of the 3-O-E-p-coumaroylalphitolic acid $\left(\mathrm{IC}_{50}=2.3 \mu \mathrm{g} / \mathrm{ml}\right)$ was significantly higher than the activity produced by alphitolic acid $\left(\mathrm{IC}_{50}\right.$ $=35 \mu \mathrm{g} / \mathrm{ml}$ ) and the related betulinic acid found in the plant against chloroquine-sensitive P. falciparum [5].

The in vivo antimalarial activity of dichloromethane extract of $C$. tinctorium investigated against plasmodium berghei has shown a significant antiplasmodial activity $\left(\mathrm{IC}_{50}=17.59 \mathrm{mg} / \mathrm{kg}\right)$ [33]. The aqueous extract of $C$. tinctorium also produced effective antiplasmodial activity possibly due to the presence of triterpenes, carotenoids, and flavonoids [33].

The petroleum ether fraction of C. tinctorium (50, 100 , and $200 \mathrm{mg} / \mathrm{kg}$ ) produced non-dose-dependent antiplasmodial activity $(80.67 \%, 64.14 \%$, and $69.71 \%)$ respectively against Plasmodium berghei [34]. Indeed, the lowest dose of the fraction $(50 \mathrm{mg} / \mathrm{kg})$ demonstrated the highest antiplasmodial activity [34]. In the same study, the ethanolic fraction of C. tinctorium (25, 50, and 100 $\mathrm{mg} / \mathrm{kg}$ ) produced a significant and dose-dependent antiplasmodial activity $(62.42 \%, 65.70 \%$, and $98.17 \%)$ respectively [34]. The highest dose of the ethanol fraction $(100 \mathrm{mg} / \mathrm{kg})$ produced antiplasmodial activity in a similar manner to the standard drug, chloroquine $(5 \mathrm{mg} / \mathrm{kg})$ [34]. The mean percentage antiplasmodial activity of the ethanol fraction $(62.90 \%)$ was slightly higher than the activity of the petroleum ether fraction (62.26\%) [34].

Table 3 Pharmacological activities of various extracts of Cochlospermum tinctorium

\begin{tabular}{|c|c|c|c|c|}
\hline Activity & Solvent & Plant part & Assay & References \\
\hline \multirow[t]{3}{*}{ Antiplasmodial } & Aqueous and oil & Leaves & In vitro & [32] \\
\hline & Dichloromethane fraction & Roots & In vivo & {$[5,33]$} \\
\hline & Petroleum ether and ethanol & Root bark & In vivo & [34] \\
\hline Antiulcer & Aqueous & Roots & In vivo & [15] \\
\hline Anti-adhesive & Aqueous & Roots & In vitro & [14] \\
\hline Antioxidant & Aqueous & Roots & In vitro & {$[15,18]$} \\
\hline Antimicrobial & Methanol, n-hexane, ethylacetate, aqueous & Roots, leaves & In vitro & {$[22,24-26]$} \\
\hline Antihelmintic & Ethanol & Shoot & In vitro & [23] \\
\hline \multirow[t]{2}{*}{ Cytotoxicity } & Acetone and butanol & Rhizomes & In vitro & [13] \\
\hline & $\begin{array}{l}\text { Ethanol, methanol, n-hexane, chloroform, aqueous, } \\
\text { ethylacetate, and petroleum ether }\end{array}$ & Roots, leaves & In vitro & {$[26,32,44]$} \\
\hline \multirow[t]{3}{*}{ Hepatoprotective } & Aqueous & Roots & In vivo & [28-30] \\
\hline & Methanol, ethanol, aqueous, and hydroethanolic & Rhizomes & In vivo and in vitro & {$[21,27]$} \\
\hline & Aqueous and methanol & Leaves & In vivo & {$[6,31]$} \\
\hline Analgesic & Aqueous methanol & Leaves, root bark and roots & In vivo & [20] \\
\hline Antiinflammatory & Aqueous methanol & Leaves, root bark and roots & In vivo & [20] \\
\hline Anticonvulsant & Hydroalcoholic & Root bark & In vivo & [19] \\
\hline Antidiarrhoeal & Aqueous methanol & Leaves & In vivo and in vitro & [22] \\
\hline
\end{tabular}


Therefore, the ethanol fraction was reported to be more effective and potent than the petroleum ether fraction [34]. Additionally, the petroleum ether fraction (50, 100, and $200 \mathrm{mg} / \mathrm{kg}$ ) produced non-dose-dependent mean packed cell volume (PCV) of 36.83\%, 32.42\%, and $37.96 \%$ respectively [34]. Similarly, the ethanolic fraction $(25,50$, and $100 \mathrm{mg} / \mathrm{kg})$ revealed a mean PCV of $40.22 \%$, $27.50, \%$ and $43.04 \%$ respectively [34]. Therefore, it was suggested that the two fractions possess anemia ameliorating properties that may be associated with complication of malaria [34].

Benoit-Vical et al. reported the antiplasmodial activity of the identified compounds (3-tetradecanone and 3hexadecanone) in the essential oils obtained from whole tubercles, tubercle epiderma, and the central cylinder of C. tinctorium against two strains of Plasmodium falciparum (chloroquine resistant and chloroquine sensitive) [39]. The oil obtained from the tubercle epiderma produced the highest antiplasmodial activity $\left(\mathrm{IC}_{50}=5-53\right.$ $\mu \mathrm{g} / \mathrm{ml}$ ) [36]. In addition, the essential oil obtained from the $C$. tinctorium showed insecticidal activity against mosquitoes in West Africa [36]. These findings validate the traditional use of $C$. tinctorium as herbal medicine against malaria [5].

Anti-ulcer activity The antiulcer activity of C. tinctorium was investigated using hydrochloric acid $(\mathrm{HCl}) /$ ethanol-induced gastric ulceration model in mice [15]. The mice were administered the crude aqueous extract of C. tinctorium $1 \mathrm{~h}$ prior to the administration of 0.24 $\mathrm{ml}$ of $0.3 \mathrm{M} \mathrm{HCl}-60 \%$ ethanol orally. The polysaccharide enriched crude root extract of C. tinctorium (25, 50, and $250 \mathrm{mg} / \mathrm{kg}$ ) significantly inhibited the $\mathrm{HCl} /$ ethanol-induced gastric ulcer $(11 \%, 20 \%$, and $55 \%)$ respectively [15]. Additionally, the aqueous root extract of C. tinctorium and its most acidic fraction further demonstrated radical scavenging activities against 1,1-diphenyl-2picryl-hydrazyl $(\mathrm{DPPH})$, which is associated with the anti-ulcer activity of the extract [15]. It was suggested that the ferulic acid and polysaccharide content of $C$. tinctorium may be responsible for the antiulcer and the radical scavenging activities of the extract [15]. The purified pectins of the extract also demonstrated a moderate induction of B cell proliferation, which demonstrated a possible immune-modulating function of the extract in its ulcer healing effect [15].

Inngjerdingen et al. reported the anti-adhesive activities of the aqueous root extract and isolated pectic polysaccharide fractions of C. tinctorium against Helicobacter pylori by in vitro flow cytometric assay using human gastric adenocarcinoma epithelial cells [14]. The extract and isolated fractions demonstrated significant anti-adhesive potential against $H$. pylori which is associated with anti-ulcer activity of C. tinctorium [14]. The ulcer-healing potential exhibited by the C. tinctorium confirmed its ability and usefulness as antiulcer agent in traditional medicine [14].

Antioxidant activity The antioxidant activity of the aqueous root extract of $C$. tinctorium was evaluated using DPPH radical scavenging activity, hydroxyl radical scavenging activity, and ferric iron-reducing activity [18]. The extract produced significant antioxidant activity against DPPH radical which could be related to the presence of soluble oxalates and phytates in the plant [18]. The extract also produced remarkable hydroxyl radical scavenging activity possibly due to the presence of phenolic compounds such as hydrolysable tannins, flavonoids, alkaloids, and carotenoids [18]. Also, the ferric ironreducing activity elicited by the extract was suggested to be due to the presence of oxalates, phytates, tannins, flavonoids, alkaloids, and carotenoids [18].

Antimicrobial activity The aqueous extract of C. tinctorium rhizomes was reported to possess antibacterial activity [21]. Additionally, the antibacterial activity of the methanol root extract of C. tinctorium (500, 1000, and $2000 \mu \mathrm{g} / \mathrm{ml}$ ) was evaluated using hole-in-plate bioassay technique with ciprofloxacin $(10 \mu \mathrm{g} / \mathrm{ml})$ and gentamicin $(10 \mu \mathrm{g} / \mathrm{ml})$ as standard drugs [24]. The extract demonstrated significant antibacterial activity at $2000 \mu \mathrm{g} / \mathrm{ml}$ against Staphylococcus aureus $(19.00 \mathrm{~mm})$, Corynebacterium ulcerans $(17.20 \mathrm{~mm})$, Klebsiella pneumoniae $(11.00 \mathrm{~mm})$, Escherichia coli $(14.30 \mathrm{~mm})$, Proteus mirabilis $(11.00 \mathrm{~mm})$, and Shigella dysentriae $(19.00 \mathrm{~mm})$ [24]. The highest activity of the extract was observed against $S$. aureus and $S$. dysentriae $(19.00 \mathrm{~mm})$ [24].

The methanol root extract of C. tinctorium produced minimum inhibitory concentration (MIC) against $S$. dysentriae $(100 \mu \mathrm{g} / \mathrm{ml})$, S. aureus and C. ulcerans $(500$ $\mu \mathrm{g} / \mathrm{ml})$, E. coli and P. mirabilis $(1000 \mu \mathrm{g} / \mathrm{ml})$, and $K$. pneumoniae $(1500 \mu \mathrm{g} / \mathrm{ml})$ [24]. Also, the extract revealed minimum bactericidal concentration (MBC) against $S$. dysentriae $(500 \mu \mathrm{g} / \mathrm{ml})$, S. aureus and C. ulcerans $(1000$ $\mu \mathrm{g} / \mathrm{ml})$, E. coli and P. mirabilis $(1500 \mu \mathrm{g} / \mathrm{ml})$, and $K$. pneumoniae $(2000 \mu \mathrm{g} / \mathrm{ml})$ [24]. The rate of bactericidal activity of the extract was further determined on the two most susceptible bacterial isolates ( $S$. aureus and $S$. dysentriae) [24]. There was no viable $S$. aureus and $S$. dysentriae after 10 and $6 \mathrm{~h}$ of exposure to the extract respectively. Therefore, the extract showed higher rate of bactericidal activity against $S$. dysentriae than $S$. aureus [24]. The antibacterial activity of the methanol root extract of the plant could be due to the presence of alkaloids, flavonoids, tannins, and cardiac glycosides [24]. Flavonoids are known to possess effective antimicrobial activity against a wide range of microorganisms due to their ability to form complex with cellular proteins and 
bacterial cell walls [45]. Diallo et al. further reported the antimicrobial activity of carotenoids obtained from $C$. tinctorium against C. albicans, A. fumigatus, and E. coli [42].

The antibacterial activity of the methanol root extract of C. tinctorium was also evaluated against resistant food-borne strains of $S$. aureus and Listeria monocytogene isolated from onion, cabbage, lettuce, and tomato using agar diffusion method [25]. The extract produced the highest activity against antibiotic-resistant $S$. aureus isolates $(22.00 \mathrm{~mm})$ from tomato and L. monocytogene $(21.00 \mathrm{~mm})$ at a concentration of $10 \mathrm{mg} / \mathrm{ml}$, whereas the lowest zone of inhibition was observed against $S$. aureus $(12.00 \mathrm{~mm})$ isolated from spring onion and L. monocytogene $(13.00 \mathrm{~mm})$ at a concentration of $2.5 \mathrm{mg} / \mathrm{ml}$. The $\mathrm{MIC}$ and MBC of the extract against $S$. aureus and $L$. monocytogene isolates were found to be within the range of $0.625-2.5 \mathrm{mg} / \mathrm{ml}$ and $2.5-5 \mathrm{mg} / \mathrm{ml}$ respectively [25].

Further, Muhammad et al. reported the antibacterial activities of the methanol root extract of $C$. tinctorium and its n-hexane, ethyl acetate, and aqueous fractions (500, 1000, and $2000 \mu \mathrm{g} / \mathrm{ml}$ ) using hole-in bioassay plate method [26]. The extract produced the highest activity at $2000 \mu \mathrm{g} / \mathrm{ml}$ against Pseudomonas aeruginosa (8.72 \pm $0.26 \mathrm{~mm})$, E. coli $(20.33 \pm 0 . \mathrm{mm})$, P. specie $(16.33 \pm 0.58$ $\mathrm{mm})$, S. aureus $(15.67 \pm 0.58 \mathrm{~mm})$, and $K$. pneumoniae $(19.00 \pm 1.0 \mathrm{~mm})[26]$. All the fractions demonstrated effective antibacterial activities against all the bacterial isolates [26]. The $n$-hexane fraction produced the highest zone of inhibition against $K$. pneumoniae $(19.00 \pm 1.0$ $\mathrm{mm})$ at the highest concentration $(2000 \mu \mathrm{g} / \mathrm{ml})$ [26]. The extract also showed MICs and MBCs against E. coli (125 and $250 \mu \mathrm{g} / \mathrm{ml}$ ), K. pneumoniae (62.5 and $62.5 \mu \mathrm{g} /$ $\mathrm{ml}$ ), and $S$. aureus (125 and $125 \mu \mathrm{g} / \mathrm{ml}$ ) respectively [26].

The antimicrobial activity of the aqueous methanol leaf extract of C. tinctorium (100-200 mg/ml) was evaluated using agar diffusion assay against Salmonella typhi (Clinical isolate), Pseudomonas aeruginosa (ATCC 101465), Escherichia coli (ATCC 11775), Bacillus subtilis (NCTC 332616376), Staphylococcus aureus (ATCC 21001), and Candida albicans (clinical isolate) [22]. The extract produced various zones of inhibition at $200 \mathrm{mg} /$ $\mathrm{ml}$ against S. typhi $(49.2 \pm 1.7 \mathrm{~mm})$, B. subtilis $(20.7 \pm$ $2.7 \mathrm{~mm})$, P. aeruginosa $(21.0 \pm 2.7 \mathrm{~mm})$, S. aureus $(22.1$ $\pm 1.7 \mathrm{~mm})$, E. coli $(22.1 \pm 1.0 \mathrm{~mm})$, and C. albicans (20.1 $\pm 5.3 \mathrm{~mm}$ ) in a concentration-dependent manner [22]. The most and least susceptible organisms to the extract were S. typhi $(49.2 \pm 1.7 \mathrm{~mm})$ and Candida albicans $(20.1 \pm 5.3 \mathrm{~mm})$ respectively [22]. The antimicrobial activities exhibited by the extract and fractions of C. tinctorium showed its potential in the management of microbial infections [17].

The above investigations suggested that the extracts of C. tinctorium and its fractions possess potential antimicrobial activities. However, the studies carried out concentrated on in vitro evaluations which cannot give assurance that the extracts and fractions of the plant could show same in vivo antimicrobial activities in an intact animal. Therefore, antimicrobial evaluations using in vivo animal models infected with specific microbial agents and other clinically isolated microbial strains are required to further validate these claims. Additionally, further investigations are necessary to investigate the effects of the plant against multi-drug resistant microbial strains and elucidate the specific cellular and molecular mechanisms of antimicrobial activities of the extracts and fractions to develop novel antimicrobial agents.

Antitumor activity Arjunolic acid and its derivatives (arjunolic acid methylester, arjunolic acid triacetate) isolated from C. tinctorium rhizomes produced in vitro inhibitory activity against Epstein-Barr virus (EBV) early antigen activation in Raji cells induced by 12-Otetradecanoylphorbol-13-acetate [40]. The arjunolic acid triacetate and arjunolic acid triacetate methylester demonstrated the highest inhibitory effect [40].

Furthermore, the antitumor activity of the arjunolic acid triacetate and arjunolic acid triacetate methylester were evaluated on two-stage carcinogenesis test using dimethylbenz $[a]$ anthracen and 12-0-tetradecanoyl-phorbol-13-acetate as tumor-initiating and tumor-promoting compounds respectively [41]. The arjunolic acid compounds caused a substantial delay in the occurrence of papillomas, and reduced the number and the rate of the papillomas appearance compared to control group which demonstrated their tumor inhibitory effects [41].

A research conducted by Benoit et al. demonstrated effective cytotoxic activity $\left(\mathrm{IC}_{50}=360-500 \mu \mathrm{g} / \mathrm{ml}\right)$ of the aqueous leaf extract of $C$. tinctorium [32]. In the same study, the essential oils obtained from the leaves of $C$. tinctorium also produced cytotoxic activity $\left(\mathrm{IC}_{50}=\right.$ $1600-2000 \mu \mathrm{g} / \mathrm{ml})$ [32].

The cytotoxic effects of $80 \%$ acetone and n-butanol extracts of C. tinctorium rhizomes $(62.5,125,250,500$, and $1000 \mu \mathrm{g} / \mathrm{ml}$ ) were reported using brine shrine lethality assay [13]. The n-butanol extract $\left(\mathrm{LC}_{50}=437 \pm 8 \mu \mathrm{g} / \mathrm{ml}\right)$ was found to be twice less potent than the $80 \%$ acetone extract $\left(\mathrm{LC}_{50}=240 \pm 3 \mu \mathrm{g} / \mathrm{ml}\right)$ due to the presence of more secondary metabolites responsible for the cytotoxic activities in the acetone extract compared to the nbutanol fraction [13]. The presence of flavonoids and tannins in the acetone fraction was suggested to be responsible for its higher potency and cytotoxic activity [13].

The ethanol $\left(\mathrm{LC}_{50}=29 \mu \mathrm{g} / \mathrm{ml}\right)$, chloroform $\left(\mathrm{LC}_{50}=\right.$ $231 \mu \mathrm{g} / \mathrm{ml})$, aqueous $\left(\mathrm{LC}_{50}=8 \mu \mathrm{g} / \mathrm{ml}\right)$, ethyl acetate $\left(\mathrm{LC}_{50}=10 \mu \mathrm{g} / \mathrm{ml}\right)$, and petroleum ether $\left(\mathrm{LC}_{50}=580 \mu \mathrm{g} /\right.$ $\mathrm{ml}$ ) fractions of $C$. tinctorium root showed remarkable cytotoxic activity against brine shrimp [44]. The aqueous 
$\left(\mathrm{LC}_{50}=8 \mu \mathrm{g} / \mathrm{ml}\right)$ and ethyl acetate $\left(\mathrm{LC}_{50}=10 \mu \mathrm{g} / \mathrm{ml}\right)$ fractions demonstrated the highest cytotoxic activity, whereas the petroleum ether $\left(\mathrm{LC}_{50}=580 \mu \mathrm{g} / \mathrm{ml}\right)$ and chloroform $\left(\mathrm{LC}_{50}=231 \mu \mathrm{g} / \mathrm{ml}\right)$ fractions showed the least cytotoxic activity [44].

Muhammad et al. also reported the cytotoxic activities of the methanol root extract of $C$. tinctorium and its factions (n-hexane, ethyl acetate, and aqueous) using brine shrimp lethality test [26]. The n-hexane and ethyl acetate fractions demonstrated the highest potency $\left(\mathrm{LC}_{50}=1.175 \mu \mathrm{g} / \mathrm{ml}\right)$ followed by the methanol extract $\left(\mathrm{LC}_{50}=3.165 \mu \mathrm{g} / \mathrm{ml}\right)$. However, the aqueous fraction was the least potent $\left(\mathrm{LC}_{50}=15.019 \mu \mathrm{g} / \mathrm{ml}\right)$ [26].

Antihelminthic activity The antihelmintic activity of the ethanol shoot extract of $C$. tinctorium was evaluated against Terrestris lumbricoides, Taenia saginata, and Taenia solium using adult worm motility test with albendazole as a standard drug [23]. The extract $(25,50$, and $100 \mathrm{mg} / \mathrm{cm}^{3}$ ) produced an average paralysis time of 35.3, 57.0, and $72.0 \mathrm{~min}$ and death time of 47.2, 74.5, and 91.9 min respectively in a concentration-dependent manner against these parasites [23]. The extract demonstrated lower antihelmintic activity compared to the standard drug albendazole used at the same concentrations [23]. This pharmacological investigation is of importance in the traditional use of C. tinctorium as herbal drug against parasitic diseases such as schistosomiasis [21].

Hepatoprotective activity The aqueous roots extract of C. tinctorium (36 mg/kg, p.o) produced a promising hepatoprotective activity against aflatoxin $\mathrm{B}_{1}\left(\mathrm{AFB}_{1}\right)$-induced hepatotoxicity in albino rats [29]. The liver marker enzymes sorbitol dehydrogenase (SDH), serum glutamate pyruvic transaminase (SGFT), and serum glutamate oxalacetate transaminase (SGOT) significantly increased in the $\mathrm{AFB}_{1}$-treated rats when compared with the control group. The pretreatment of the rats with the C. tinctorium (36 mg/kg, p.o) for $72 \mathrm{~h}$ produced a significant reduction in the level of $\mathrm{AFB}_{1}$-induced elevation of the activities of the serum enzymes (SDH and SGFT) [29]. However, the extract produced non-significant decrease in the level of SGOT which is widely available in other tissues [29]. Also, the pretreatment of the rats with the extract produced significant protection against the $\mathrm{AFB}_{1}$-induced inhibition of microsomal benzphetamine $\mathrm{N}$-demethylase and aniline hydroxylase [29]. However, the extract only produced considerable but nonsignificant protection against the loss of microsomal cytochrome P-450 induced by $\mathrm{AFB}_{1}$ [29].

The methanol, ethanol, and aqueous extracts of $C$. tinctorium rhizomes were reported to have significant hepatoprotective activity against carbon tetrachloride
$\left(\mathrm{CCl}_{4}\right)$ and galactosamine-induced cytotoxicity in cultured rat hepatocytes [21]. The methanol and ethanol extracts demonstrated higher antihepatotoxic effect than the aqueous extract as a result of the presence of tannins and polyphenol compounds (gallic and ellagic acid) [21]. Additionally, carotenoids were also present in the methanol fraction which also significantly prevented $\mathrm{CCl}_{4}$-induced hepatotoxicity [21]. It was suggested that the polyphenol compounds and carotenoids may account for the antihepatotoxic activity of the plant [21].

The hepatoprotective activity of the rhizome of $C$. tinctorium was further investigated using $\mathrm{CCl}_{4}$-induced toxicity and tert-butyl hydroperoxide in vitro induction of lipid peroxidation and hepatocyte lysis [27]. The aqueous, hydro-ethanolic, and ethanolic extracts of the plant showed significant hepatoprotective activities in a dose-dependent manner [27]. The ethanolic extract was found to be more potent than the standard drug, silymarin [27]. The ethanolic and hydro-ethanolic extracts also showed remarkable activities against the induction of lipid peroxidation and hepatocyte lysis, while the aqueous extract demonstrated a weaker activity [27].

The aqueous root extract of C. tinctorium (100, 200, and $300 \mathrm{mg} / \mathrm{kg}$ ) significantly and dose-dependently reduced the levels of alanine aminotransferase (ALT), aspartate aminotransferase (AST), alkaline phosphatase (ALP), and blood clotting time, which indicated its ability to preserve hepatic function [30]. However, the levels of serum albumin, total protein, and reduced glutathione in the groups treated with the extract significantly elevated compare to the $\mathrm{CCl}_{4}$-treated group [30]. The highest hepatoprotective activity was observed in the group treated with the highest dose of the extract $(300 \mathrm{mg} / \mathrm{kg})$ which was better than the standard drug, silymarin [30]. In addition, the pretreatment of the animals with the aqueous extract of $C$. tinctorium progressively reduced the hepatic lesion and cellular damage [30]. The observed hepatoprotective action could possibly be related to the antioxidant activity of the phytochemical compounds such as flavonoids and tannins present in the extract [46].

Etuk et al. further reported the hepatocurative action of the aqueous root extract of C. tinctorium on experimentally induced liver damage following intraperitoneal administration of $\mathrm{CCl}_{4}$ for 5 days in Wistar rats [28]. The oral administration of the aqueous root extract of C. tinctorium $(200 \mathrm{mg} / \mathrm{kg})$ for 7 days after induction of hepatotoxicity with $\mathrm{CCl}_{4}$ caused a significant reduction in the blood clotting time, ALT, AST, ALP, and bilirubin [28]. The extract also increased the level of serum total protein, albumin, and reduced glutathione compared to the $\mathrm{CCl}_{4}$-treated group [28]. Also, the extract reversed the $\mathrm{CCl}_{4}$-induced hepatic damage [28]. 
The hepatocurative activity of the aqueous leaves extract of C. tinctorium (50-150 $\mathrm{mg} / \mathrm{kg}$ ) against acute liver damage following single intraperitoneal injection of $\mathrm{CCl}_{4}$ was reported by Adam et al. [31]. The $\mathrm{CCl}_{4}$ produced elevated level of ALT, AST, and cholesterol as a result of impairment of the structural integrity of the liver [31]. The treatment of the animals with the extract remarkably decreased the levels of the serum enzymes (ALT, AST, and ALP) and bilirubin and significantly increased the level of albumin [31]. The histopathological examination of the liver also revealed a dose-dependent regeneration and improvement on the structural integrity of the liver cells [31]. It was suggested that the hepatocurative potential of the extract may be attributed to the presence of tannins, carotenoids, gallic, and ellergic acids [31].

In 2012, Akinloye and Ayankojo reported a significant reduction in the levels of SGFT, SGOT, cholesterol, urea, and bilirubin after oral administration of methanol leaf extract of C. tinctorium $(200 \mathrm{mg} / \mathrm{kg})$ in $\mathrm{CCl}_{4}$-induced hepatotoxicity [6]. The extract also remarkably prevented lipid peroxidation of hepatocytes demonstrated by a significant reduction in the level of malondialdehyde (MDA) compared to the $\mathrm{CCl}_{4}$-treated [6]. Additionally, the extract demonstrated evidence of hepatocytes regeneration which gives an evidence of its moderate hepatoprotective activity against $\mathrm{CCl}_{4}$-induced liver damage [6].

Analgesic activity The analgesic activity of the aqueous methanol leaf extract (AMLE), root bark extract (AMRBE), and root extract (AMRE) of C. tinctorium were reported by Ahmed and colleagues using acetic acid-induced writhing and hot plate tests in mice [20]. The extracts produced significant and dose-dependent protection against the acetic acid-induced abdominal writhing [20]. The AMLE showed the highest protection against the acetic acid-induced abdominal constrictions at the dose of $80 \mathrm{mg} / \mathrm{kg}$ which was greater than of the standard drug, ketoprofen (82.30\%) [20]. The AMRBE produced a non-dose-dependent increase in the mean latency of pain response in hot plate test which was only significant at the dose of $20 \mathrm{mg} / \mathrm{kg}$ [20].

Anti-inflammatory activity Ahmed et al. reported the anti-inflammatory activity of $C$. tinctorium using carrageenan-induced paw edema in rats. The AMRE and AMRBE of $C$. tinctorium produced a non-dose-dependent protection against the carrageenan induced-paw edema [20]. Also, the AMLE significantly and dose-dependently inhibited the carrageenan induced-hind paw edema. The highest inhibitory effect of the extract was observed in the group treated with the highest dose of the extract $(80 \mathrm{mg} / \mathrm{kg})$ [20].
Anticonvulsant activity The anticonvulsant activity of the hydro-alcoholic root bark extract of C. tinctorium (5, 10 , and $20 \mathrm{mg} / \mathrm{kg}$ ) was investigated using maximal electroshock (MES) test in chicks, pentylenetetrazole (PTZ), and strychnine-induced seizures in mice [19]. The extract at all the doses did not produce any protection against MES and strychnine-induced seizures [19]. However, the extract showed non-significant protection (20\%) against PTZ-induced seizures at the highest dose $(20 \mathrm{mg} / \mathrm{kg}$ ) [19]. Therefore, the extract may not have potential in the management of generalized tonic-clonic and absence or clonic seizures [19]. Therefore, based on the reported traditional use of $C$. tinctorium in the management of epilepsy, other parts of the plant are recommended to be thoroughly screened in order to validate its claimed antiepileptic activity as reported in traditional medicine using other different solvents in order to obtain extracts or fractions that may contain potential antiepileptic compounds.

Antidiarrhoeal activity The antidiarrhoeal potential of the aqueous methanol leaf extract of C. tinctorium (20, 40 , and $80 \mathrm{mg} / \mathrm{kg}$ ) was evaluated using castor oilinduced diarrhea in mice and isolated rabbit jejunum preparation [22]. The extract demonstrated significant and non-dose-dependent inhibition of diarrhea [22]. The highest $(80 \mathrm{mg} / \mathrm{kg})$ and lowest dose $(20 \mathrm{mg} / \mathrm{kg})$ of the extract produced $100 \%$ protection against diarrhea compared to the standard drug, loperamide $(5 \mathrm{mg} / \mathrm{kg})$ [22]. The extract also inhibited spontaneous muscle contraction of the rabbit jejunum at all the concentration tested $(0.32-3.2 \mathrm{mg} / \mathrm{ml})$. This study confirmed the traditional use of the plant in the management of diarrhea [22].

\section{Toxicology}

Herbal medicines have gained patronage in developing and developed countries as a result of their effectiveness and safety [47]. However, the safety of the medicinal plants could not be guaranteed despite their wide use [47]. Many scientific studies have shown that many of the herbal plants used as food or medicines are potentially toxic, mutagenic, and carcinogenic [47]. Therefore, it is essential to evaluate and document their safety to determine the consequences of their long use for drug development.

Acute oral administration of the aqueous root extract of C. tinctorium did not produce any death and symptoms of toxicity at the dose of $5000 \mathrm{mg} / \mathrm{kg}$ which suggested that the extract is relatively safe following acute oral administration [48]. The intraperitoneal median lethal doses $\left(\mathrm{LD}_{50}\right)$ of the AMRE, AMLE, AMRBE, and hydro-alcoholic root extract were reported to be 118.32, $288.53,288.53$, and $118.32 \mathrm{mg} / \mathrm{kg}$ respectively $[19,20]$. 
It is well known that researches always focus to discover and develop potent, efficacious, and safe bioactive compounds because chemical substances obtained from the plants play a key role in the development of conventional drugs [35]. Based on the reported therapeutic potentials of $C$. tinctorium in the treatment of various diseases in African countries, to date, substantial toxicity studies on the extracts, fractions, and isolated compounds from the plant are lacking to support its safety. Therefore, it is highly recommended for a throughput long term (sub-acute, sub-chronic, chronic, carcinogenic, mutagenic, and teratogenic) toxicity studies on the extracts, fractions, and isolated compounds from C. tinctorium to be conducted in animal models to further increase confidence in its use and ascertain its safety for drug development. It is also worthy to note that the pharmacokinetics (absorption, distribution, metabolism, and excretion) studies have not been investigated.

\section{Conclusion}

The plant C. tinctorium is an important medicinal plant with promising therapeutic potentials. Previous pharmacological investigations conducted on C. tinctorium provided supportive evidence for some of the documented traditional uses of the plant. However, many of the reported traditional uses of $C$. tinctorium still lack scientific evidence; hence, the need for more scientific investigations to authenticate the folkloric uses of the plant. Moreover, among the isolated bioactive compounds of $C$. tinctorium, only few were screened for biological activities. Therefore, extensive phytochemical and further pre-clinical studies could be done in the future to fully establish its therapeutic potentials and elucidate its detailed mechanisms of pharmacological actions. Finally, there is lack of information on safety profile of C. tinctorium. Therefore, toxicological studies on the extracts, fractions, and isolated bioactive compounds of $C$. tinctorium should be performed to further ascertain their safety aspect.

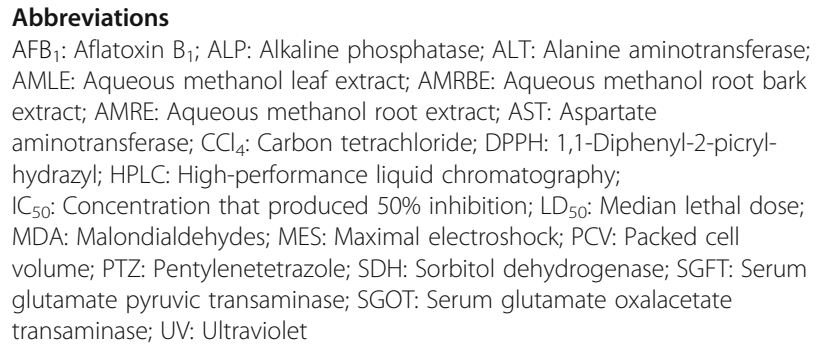
AMLE: Aqueous methanol leaf extract; AMRBE: Aqueous methanol root bark extract; AMRE: Aqueous methanol root extract; AST: Aspartate aminotransferase; $\mathrm{CCl}_{4}$ : Carbon tetrachloride; DPPH: 1,1-Diphenyl-2-picrylhydrazyl; HPLC: High-performance liquid chromatography; ${ }^{1} \mathrm{C}_{50}$ : Concentration that produced $50 \%$ inhibition; $\mathrm{LD}_{50}$ : Median lethal dose; MDA: Malondialdehydes; MES: Maximal electroshock; PCV: Packed cell volume; PTZ: Pentylenetetrazole; SDH: Sorbitol dehydrogenase; SGFT: Serum glutamate pyruvic transaminase; SGOT: Serum glutamate oxalacetate transaminase; UV: Ultraviolet

\section{Acknowledgements}

The authors are thankful to all members of Young Pharmacists Scholars (YPS), a mentorship forum for their continuous support and guidance.

\section{Authors' contributions}

MHA substantially contributed to the conception and designing of the work and drafted the manuscript, AlJ contributed to the writing of the manuscript and substantially revised the whole manuscript, GMK contributed to the writing of the manuscript and substantially revised the whole manuscript, and OYA contributed to the writing of the manuscript and substantially revised the whole manuscript. All authors have read and approved the manuscript.

\section{Funding}

Not applicable.

Availability of data and materials

Not applicable.

Ethics approval and consent to participate

Not applicable.

Consent for publication

Not applicable.

\section{Competing interests}

The authors declare that they have no competing interests.

\section{Author details}

${ }^{1}$ Department of Pharmacology and Therapeutics, Ahmadu Bello University, Zaria, Nigeria. ${ }^{2}$ School of Pharmacy Technician, Aminu Dabo College of Health Sciences and Technology, Kano, Nigeria. ${ }^{3}$ School of Pharmacy and Pharmacology, University of Tasmania, Hobart, Tas 7005, Australia. ${ }^{4}$ Faculty of Pharmaceutical Sciences, Bayero University, Kano P.M.B. 3011, Nigeria.

${ }^{5}$ Department of Pharmaceutical Sciences, Università degli Studi di Milano, Via G. Colombo, 71, 20133 Milan, Italy. ${ }^{6}$ College of Pharmacy, Riyadh Elm University, Qurtoba 11681, Riyadh, Saudi Arabia.

Received: 14 August 2020 Accepted: 26 December 2020

Published online: 14 January 2021

\section{References}

1. Sen T, Samanta SK (2014) Medicinal plants, human health and biodiversity: a broad review. Adv Biochem Eng Biotechnol 147:59-110. https://doi.org/10. 1007/10_2014_273

2. Martins J, Brijesh S (2018) Phytochemistry and pharmacology of antidepressant medicinal plants: A review. Biomed Pharmacother 104:343-365. https://doi.org/10.1016/j.biopha.2018.05.044

3. Tekuri SK, Pasupuleti SK, Konidala KK, Pabbaraju N (2019) Pharmacological effects of Polyalthia cerasoides (Roxb.) Bedd.: A brief review. J Complement Med Res 10(1):38-49. https://doi.org/10.5455/jcmr.20190108065022

4. Ballin NZ, Traore M, Tinto H, Sittie A, Mølgaard P, Olsen CE, Kharazmi A, Christensen SB (2002) Antiplasmodial compounds from Cochlospermum tinctorium. J Nat Prod 65(9):1325-1327. https://doi.org/10.1021/np020008h

5. Akinloye OA, Ayankojo AG, Olaniyi MO (2012) Hepatoprotective Activity of Cochlospermum tinctorium against carbon tetrachloride induced hepatotoxicity in rats. J Biochem 49:3-12

6. Haidara M, Bourdy G, De Tommasi N (2016) Medicinal plants used in Mali for the treatment of malaria and liver diseases. Nat Prod Commun 11(3): 339-352. https://doi.org/10.1177/1934578x1601100309

7. Aguilar-Guadarrama A, Rios MY (2018) Flavonoids, sterols and lignans from Cochlospermum vitifolium and their relationship with its liver activity. Molecules 23(8):1952-1959. https://doi.org/10.3390/molecules23081952

8. Johnson-Fulton SB, Watson LE (2018) Comparing medicinal uses of Cochlospermaceae throughout its geographic range with insights from molecular phylogenetics. Diversity 10(4):123-141. https://doi.org/10.3390/ d10040123

9. Lamien-Meda A, Kiendrebeogo M, Compaoré M, Meda RNT, Bacher M, Koenig K, Pacher T, Fuehrer HP, Noedl H, Willcox M, Novak J (2015) Quality assessment and antiplasmodial activity of West African Cochlospermum species. Phytochemistry 119:51-61. https://doi.org/10.1016/j.phytochem. 2015.09.006

10. Jansen PCM (2005) Cochlospermum tinctorium Perr. ex A. Rich. In: Jansen PCM, Cardon D (eds) PROTA (plant resources of tropical Africa), Wageningen, Netherlands Available from https://uses.plantnet-project.org/ en/Cochlospermum_tinctorium_(PROTA). Accessed on 12 July 2020 
11. The plant Cochlospermum tinctorium A. Rich (Cochlospermaceae) in its natural habitat. Adopted from http://www.westafricanplants.senckenberg.de. Accessed on 30 June 2020.

12. Abdulaziz R, Usman MH, Ibrahim UB, Tambari BM, Nafiu A, Jumare IF, Said MA, Ibrahim AD (2019) Studies on the antibacterial activity and chemical composition of methanol extract of Cochlospermum tinctorium root. Asian Plant Res J 2(3):1-11. https://doi.org/10.9734/aprj/2019/v2i330049

13. Musa AA (2012) Cytotoxicity activity and phytochemical screening of Cochlospermum tinctorium perr ex A. Rich rhizome. J Appl Pharm Sci 2(7): 155-159. https://doi.org/10.7324/JAPS.2012.2723

14. Inngjerdingen KT, Thole C, Diallo D, Paulsen BS, Hensel A (2014) Inhibition of Helicobacter pylori adhesion to human gastric adenocarcinoma epithelial cells by aqueous extracts and pectic polysaccharides from the roots of Cochlospermum tinctorium A. Rich. and Vernonia kotschyana Sch. Bip. ex Walp. Fitoterapia 95:127-132. https://doi.org/10.1016/j.fitote.2014.03.009

15. Nergard CS, Diallo D, Inngjerdingen K (2005) Medicinal use of Cochlospermum tinctorium in Mali: Anti-ulcer-, radical scavenging- and immunomodulating activities of polymers in the aqueous extract of the roots. J Ethnopharmacol 96(1-2):255-269. https://doi.org/10.1016/j.jep.2004. 09.018

16. Igoli JO, Igwue IC, Igoli NP (2004) Traditional medicinal practices among the Igede people of Nigeria. J Herbs Spices Med Plants 10(4):1-10. https://doi. org/10.1300/J044v10n04_01

17. Magassouba FB, Diallo A, Kouyaté M, Mara F, Mara O, Bangoura O, Camara A, Traoré S, Diallo AK, Zaoro M, Lamah K, Diallo S, Camara G, Traoré S, Kéita A, Camara MK, Barry R, Kéita S, Oularé K, Barry MS, Donzo M, Camara K, Toté K, Berghe DV, Totté J, Pieters L, Vlietinck AJ, Baldé AM (2007) Ethnobotanical survey and antibacterial activity of some plants used in Guinean traditional medicine. J Ethnopharmacol 114(1):44-53. https://doi.org/10.1016/j.jep.2007. 07.009

18. Ndouyang CJ, Kaptso G, Nguimbou RM, Scher J, Gaiani C, Facho B (2018) Relationship between secondary metabolites, antiradical activities, and colour characteristics of Cochlospermum Tinctorium A. Rich. (Bixaceae) Root. Ghana J Sci 59:79-92. https://doi.org/10.4314/gjs.v59i1.7

19. Maiha BB, Magaji MG, Yaro AH, Hamza AH, Ahmed SJ, Magaji AR (2009) Anticonvulsant studies on Cochlospermum tinctorium and Paullinia pinnata extracts in laboratory animals. Niger J Pharm Sci 8(1):102-108

20. Ahmed TS, Magaji MG, Yaro AH, Musa AM, Adamu AK (2011) Aqueous methanol extracts of Cochlospermum tinctorium (A. Rich) possess analgesic and anti-inflammatory activities. J Young Pharm 3(3):237-242. https://doi. org/10.4103/0975-1483.83774

21. Diallo B, Vanhaelen M, Kiso Y, Hikino H (1987) Antihepatotoxic actions of Cochlospermum tinctorium rhizomes. J Ethnopharmacol 20(3):239-243. https://doi.org/10.1016/0378-8741(87)90051-1

22. Magaji MG, Shehu A, Sani MB, Musa AM, Yaro AH, Ahmed TS (2010) Biological activities of aqueous methanol leaf extract Cochlospermum tinctorium A Rich. Niger J Pharm Sci 1:36-43

23. Garba S, Adeyemi MM, Musa LK (2019) Anthelmintic activities of hexacosa-9, 11-dienoic acid and 3-hydroxyurs-12-en-28-oic acid isolated from Spermacoce verticillata. Chem Sci Int J 28(1):1-10. https://doi.org/10.9734/ CSJI/2019/v28i130131

24. Tijjani MB, Bello IA, Aliyu AB, Olurishe T, Maidawa SM, Habila JD, Balogun EO (2009) Phytochemical and antibacterial studies of root extract of Cochlospermum tinctorium A. Rich. (Cochlospermaceae). Res J Med Plant 3(1):16-22. https://doi.org/10.3923/rjmp.2009.16.22

25. Abdulaziz R, Usman MH, Ibrahim UB (2019) Studies on the antibacterial activity and chemical composition of methanol extract of Cochlospermum tinctorium Root. Asian Plant Res J 2(3):1-11. https://doi.org/10.9734/aprj/ 2019/v2i330049

26. Muhammad AU, Taura DW, Abubakar YU, Dalhat AD, Inuwa AM, Aliyu SM, Kabir RM, Rabil AK (2020) Cytotoxicity and antibacterial activities of methanol extract of Cochlospermum tinctorium roots and its fractions. Adv Pharm J 5(1):14-20. https://doi.org/10.31024/apj.2020.5.1.3

27. Diallo B, Vanhaelen-Fastre R, Vanhaelen M, Fiegel C, Joyeux M, Roland A, Fleurentin J (1992) Further studies on the hepatoprotective effects of Cochlospermum tinctorium rhizomes. J Ethnopharmacol 36(2):137-142. https://doi.org/10.1016/0378-8741(92)90013-H

28. Etuk EU, Francis UU, Garba I (2009) Regenerative action of Cochlospermum tinctorium aqueous root extract on experimentally induced hepatic damage in rats. Afr J Biochem Res 3(1):001-004. https://doi.org/10.5897/AJBR. 9000205
29. Dalvi RR, Sere A (1988) Protective effect of Cochlospermum tinctorium A. Rich extract versus aflatoxin b induced liver damage in rats. Pharm Biol 26(2):117-120. https://doi.org/10.3109/13880208809053903

30. Etuk EU, Agaie BM, Ladan MJ, Garba I (2009) The modulatory effect of Cochlospermum tinctorium a rich aqueous root extract on liver damage induced by carbon tetrachloride in rats. Afr J Pharm Pharmacol 3(4):151157. https://doi.org/10.5897/AJPP.9000271

31. Adam AA, Muhammad BY, Sani AM (2015) Hepatocurative effect of aqueous leaves extracts of Negro coffee (Cochlospermum tinctorium) on carbon tetrachloride induced liver injury in rats. Pakistan J Biochem Mol Biol 48(4): 97-100

32. Benoit-Vical F, Valentin A, Mallie M, Bastide JM, Bessiere JM (1999) In vitro antimalarial activity and cytotoxicity of Cochlospermum tinctorium and C. planchonii leaf extracts and essential oils. Planta Med 65(4):378-381. https:// doi.org/10.1055/s-2006-960794

33. Traoré M, Guiguemdé A, Yago I, Nikièma JB, Tinto $H$, Dakuyo ZP, Ouédraogo JB, Guissou IP, Guiguemdé TR (2006) Investigation of antiplasmodial compounds from two plants, Cochlospermum tinctorium A. rich and Gardenia sokotensis hutch. Afr J Tradit Complement Altern Med 3(4):34-41 https://journals.athmsi.org/index. php/ajtcam/article/view/87

34. Ahmadu RO, Kogi E, Ndams IS (2014) Antiplasmodial activity of the root extracts of Cochlospermum tinctorium in mice experimentally infected with clinical isolates of Plasmodium berghei berghei (NK 65). J Pharm Res Int 4(8): 895-909. https://doi.org/10.9734/BJPR/2014/6861

35. Senthilkumar A, Karuvantevida N, Rastrelli L, Kurup SS, Cheruth AJ (2018) Traditional uses, pharmacological efficacy, and phytochemistry of Moringa peregrina (Forssk.) Fiori.-A Review. Front Pharmacol 9:465-481. https://doi. org/10.3389/fphar.2018.00465

36. Bossou AD, Mangelinckx S, Yedomonhan H, Boko PM, Akogbeto MC, De Kimpe N, Avlessi F, Sohounhloue DCK (2013) Chemical composition and insecticidal activity of plant essential oils from Benin against Anopheles gambiae (Giles). Parasit Vectors 6:337. https://doi. org/10.1186/1756-3305-6-337

37. Diallo B, Vanhaelen-Fastre R, Vanhaelen M (1991) Triacylbenzenes and longchain volatile ketones from Cochlospermum tinctorium rhizome. Phytochemistry 30(12):4153-4156. https://doi.org/10.1016/0031 9422(91)83485-4

38. Bragagna L, Traoré Coulibaly M, Stolze K, Ouédraogo JC, Yougbaré S, Dakuyo ZP, Novak J (2019) Spectrophotometric determination of antiplasmodial cochloxanthins from roots of Cochlospermum planchonii Hook.f. (Bixaceae). Sci African 2:e00055. https://doi.org/10.1016/j.sciaf. 2019.e00055

39. Benoit-Vical F, Valentin A, Mallie M, Bessiere JM (2001) Antiplasmodial activity of Cochlospermum planchonii and C. tinctorium tubercle essential oils. J Essent Oil Res 13(1):65-67. https://doi.org/10.1080/ 10412905.2001.9699609

40. Diallo B, Vanhaelen M, Vanhaelen-Fastre R (1989) Studies on inhibitors of skin-tumor promotion. Inhibitory effects of triterpenes from Cochlospermum tinctorium on Epstein-Barr virus activation. J Nat prod 52(4):879-881. https:// doi.org/10.1021/np50064a039

41. Diallo B, Vanhaelen-Fastre R, Vanhaelen M, Konoshima T, Takasaki M, Tokuda $H$ (1995) In vivo inhibitory effects of arjunolic acid derivatives on two-stage carcinogenesis in mouse skin. Phytother Res 9(6):444-447. https://doi.org/10. 1002/ptr.2650090612

42. Diallo B, Vanhaelen Fastre R, Vanhaelen M, Nkiani-Ibwala NY, Coremans J (1991) Antimicrobial activity of two apocarotenoids isolated from Cochlospermum tinctorium rhizome. Fitoterapia 62(2):144-145

43. Onyeji CO, Igbinoba SI, Olayiwola G, Adehin A (2017) Insight into clinically effective herbal antimalarial products: Effects on drug metabolizing enzymes and p-glycoprotein. Afr J Pharm Pharmacol 11(48):591-613. https://doi.org/10.5897/AJPP2017.4870

44. Adoum OA (2010) Determination of toxicity levels of some savannah plants using Brine Shrimp Test (BST). Bayero J Pure Appl Sci 2(1):135-138. https:// doi.org/10.4314/bajopas.v2i1.58525

45. Cowan MM (1999) Plant products as antimicrobial agents. Clin Microbiol Rev 12(4):564-582. https://doi.org/10.1128/CMR.12.4.564

46. Zhao Y, Zhai D, Chen X (2007) Ketoprofen glucuronidation and bile excretion in carbon tetrachloride and alpha-naphthylisothiocyanate induced hepatic injury rats. Toxicology 230(2-3):145-150. https://doi.org/10.1016/j.tox. 2006.11.008 
47. Unuofin JO, Otunola GA, Afolayan AJ (2018) Acute and subacute toxicity of aqueous extract of the tuber of Kedrostis africana (L.) Cogn in Wistar rats. J Complement Integr Med 15(4):20170139. https://doi.org/ 10.1515/jcim-2017-0139

48. Li Y, Kandhare AD, Mukherjee AA, Bodhankar SL (2019) Acute and subchronic oral toxicity studies of hesperidin isolated from orange peel extract in Sprague Dawley rats. Regul Toxicol Pharmacol 105:77-85. https://doi.org/ 10.1016/.yrtph.2019.04.001

\section{Publisher's Note}

Springer Nature remains neutral with regard to jurisdictional claims in published maps and institutional affiliations.

\section{Submit your manuscript to a SpringerOpen ${ }^{\mathcal{O}}$ journal and benefit from:}

- Convenient online submission

- Rigorous peer review

- Open access: articles freely available online

- High visibility within the field

- Retaining the copyright to your article

Submit your next manuscript at $\boldsymbol{\nabla}$ springeropen.com 